\title{
Effect of Aqueous Extract of Vitis Vinifera I. Leaf on the Rabbit Females Have Highly Thyroxine Induced by Levothyroxine Sodium
}

\author{
Taghreed U.Mohammd ${ }^{1 *}$ Bushra H.Ali ${ }^{1}$ Rajaa K.Baker ${ }^{1}$
}

Dheefaf F. Hassan ${ }^{1}$

1Chemistry department, Colloge of Education for Pure Science - Ibn-

Al-Haitham, Baghdad University, Baghdad, Iraq

tagreedaloom@gmail.com; dr.bushra750@yahoo.com; Dh73falah@yahoo.com;

\section{ABSTRACT}

\section{Rajaaka1@gmail.com}

L-Thyroxine(T4) and triiodothyronine(T3)are iodine-containing hormones produced from thyroglobulin in the thyroid follicular cells. The stimulation of metabolic rate and regulation of growth and development by these hormones appear to be due to their effects on DNA transcription and, thus, protein synthesis. The aqueous extract of vitis vinifera $L$. was investigated for its effect on hormones in rabbits. The aqueous extract of plant at a dose level of $50 \mu \mathrm{g} / \mathrm{rabbit}$ showed highly significant $(\mathrm{p}<0.05)$ on levels of hormones T4, TSH but TSH no significant. L-thyroxine sodium treated group showed a highlysignificant increase in T3 and T4 while there was a highly significant decrease in TSH. From the above results, it is concluded for the first time that aqueous vitvs vinifera L. extract offers significant effect of T3, T4 and TSH in this rabbit females compared with control.

Keyword: Vitis Vinifera L., Levo thyroxine sodium; TSH,T3,T4.

Abbreviations: TSH, Thyroid stimulating hormone;T3,Triiodothyronine; T4, Thyroxine.

\section{Council for Innovative Research}

\author{
Peer Review Research Publishing System
}

\section{Journal: Journal of Advances in Chemistry}

\author{
Vol. 4, No. 3 \\ editor@cirworld.com \\ www.cirworld.com, member.cirworld.com
}




\section{INTRODUCTION}

Vitis vinifera L. (grape) is a perennial woody vine native to Asia Minor and then introduced in Europe and other continents[1]. It is a liana growing to 35 yards tall, with flasky bark. The leaves are alternate, palmately lobed, 5-20 cm long and broad. The fruit is a green, known as a grape; in the wild species it is $6 \mathrm{~mm}$ diameter and ripens dark purple to blackish with a pale wax bloom;in cultivated plants it is usually much larger, up to $3 \mathrm{~cm}$ long, and can be green, red, or purple (black). The species typically occurs in humid forests and streamsides.[2] Different parts of plant, particularly the fruits, used in folk medicine. Among the most interesting constituents responsible for the therapeutically properties of the plant, procyanidins are used for the treatment of microcirculatory disorders [3]. The leaves of Vitis vinifera (Vitaceae) is used in traditional food (dolmathes) in some Mediterranean countries and in folk medicine used for the treatment of diarrhea and vomiting[4]. Grape leaves with antioxidant activity[4]have been reported to treat chronic venous insufficiency in human[5] and nephrotoxicosis induced by citrinin[6]. It has also been demonstrated that the grape leaf hydro- alcoholic extract (GLHE) induces spasmolytic effect on rat uterus precontracted by oxytocine[6] and the same extract induces vasorelaxant effect on rat isolated aorta[7].

\section{Thyroxine}

Thyroxine $(3,5,3$ ',5'- tetraiodothyronine) show figure(1), is one of the most important hormones of the thyroid gland. It has a vital role in normal growth and development of the body and in the maturation of sexual organs. It is used to make up a hormonal deficiency on a regular maintenance basis and to treat the associated syndrome (myxoedma). It may also be used in the treatment of goiter and thyroid cancer [8]. It has L- and D- forms. The L- form is twice as active physiologically as the racemic product, and the D-form has very little activity [9].

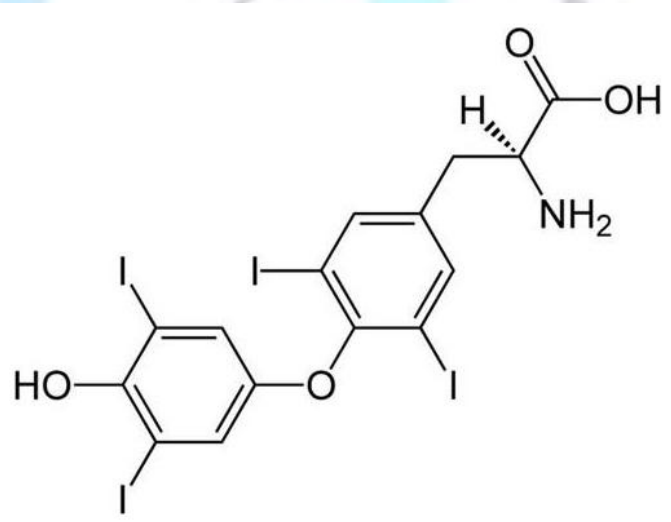

Fig 1: Structure of thyroxine [10]

The aim of this study was to evaluate the effect of the aqueous extract of Vitis vinifera L.on $\mathrm{T}_{3}, \mathrm{~T}_{4}$ and $\mathrm{TSH}$ levels in rabbit females have thyrotoxicosis induced by levothyroxine sodium.

\section{MATERIALS AND METHODS}

Samples of whole dried Vitis vinifera L. were brought from Iraqi market in Baghdad, then aerial parts of the plant were isolated and kept in airtight glass containers till the time of the experiment. Then the dried plant was ground to fine powder. $25 \mathrm{gm}$ of the powder, mixed with $250 \mathrm{~mL}$ of distilled water and were incubated for $3 \mathrm{hrs}$ at $(60)^{\circ} \mathrm{C}$ then incubated overnight at room temperature. Suspension was then filtered. Water extracts were prepared daily just before administration orally to the experimental animals in a dose of $(5 \mathrm{~mL} / \mathrm{rabbitof}(1.5-2) \mathrm{kg})$.

Preparation of levothyroxine sodium: Fresh solution of levothyroxine sodium was prepared (tablet dissolve in water or food) just before feeding. For the animals given the levothyroxine sodium (50 $\mu \mathrm{g} / \mathrm{each}$ rabbit.

Experimental animals: Eighteen female oryciolagus cuniculus rabbit (1.5-2 Kg. each) were kindly supplied by city of Medicine, for the period from September 2012 to May 2013. And were used in this research. Rabbit were maintained with free access to water and diet (containing multivitamins, vegetables, and wheat). Experimental animals were divided into two groups (9 rabbit each):

1- Control group: rabbit were orally administered (using a feeding solution) daily for 2 months;

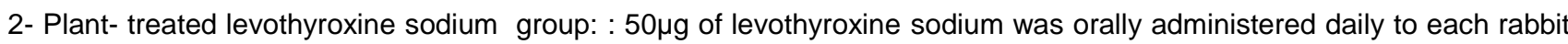
in this group for 1 month, then $5 \mathrm{~mL}$ of the plant extract $(100 \mathrm{mg} / \mathrm{mL})$ was orally administered daily to each rabbit in this group for 2 month.

Blood sampling: Blood samples were collected from the heart of rabbit using heparinized capillary tubes. Serum was separated from blood samples, then frozen until used. 
The levels of hormones(T3,T4 and TSH) in the serum were measured by ELSA(Human Germany), provided from Monobind Inc (11) .

Preliminary phytochemical screening: The tests were done to check the presence of the active chemical constituents such as alkaloids, phenolic content, carbohydrates, reducing sugar, amino acid and protein, tanine, and saponins by the following procedure:

1- Test for alkaloids, [12].

2- Test for phenolic content [13].

3- Test for carbohydrates [14].

4- Test for reducing sugar [15].

5- Test for tanine [16].

6- Test for amino acid and protein [17].

7- test of saponins[18].

Statistical analysis: All statistical analysis of the study were done using SPSS version 15.0 for Windows (statistical Package for Social Science, Inc., Chicago, IL, USA).

Descriptive analysis was used to show the mean \pm standard deviation of variables. The significance of difference between mean values was estimated by Student $T$ - test. The probability $p<0.05=$ significant.

\section{RESULTS AND DISCUSSION}

The dialy oral treatment with in dose $50 \mu \mathrm{g} / \mathrm{rabbit}$ resulted in the development of L.thyroxine after 2 weeks of administration, the effect gradually increasing over for one month period to reach arise of about once and half times over intal values compared with healthy rabbits. The aqueous extract of vitis vinifera leaves was administrated orally $100 \mathrm{mg} / \mathrm{ml}$ to each hyperthyroid rabbit to assess the effect of the plant exracts. Table(1) showed results of phytochemical screening of aqueous extract of vitis viniferal L. leaves.

Table 1. Result of phytochemical screening of aqueous extract of plant.

Table 1. Result of phytochemical screening of aqueous extract of plant.
\begin{tabular}{|c|c|}
\hline Pytochemical class & Aqueous extract \\
\hline Alkaloids & + \\
\hline Phenolic content & + \\
\hline Carbohydrates & + \\
\hline Reducing sugar & + \\
\hline Tannins & + \\
\hline Proteins & + \\
\hline Saponins & + \\
\hline
\end{tabular}

Table(2) shows the hormone levels in the two studies groups. There was significant increase in the levels of the thyroid when compared with the control animals. For $C^{\star}$ given the levothyroxin sodium $(50 \mu /$ rabbit), the levels of these thyroid hormones were significant compared with $\mathrm{C}$. 
Table 2. Illustrate values of T3, T4, and TSH level in blood rabbit females.

\begin{tabular}{|c|c|c|c|c|c|c|c|c|}
\hline & Control & L.Thyroxine & & L.Thyroxin & \multicolumn{4}{|c|}{$p$-value } \\
\hline & Mean \pm SEM & Mean士SEM & Mean \pm SEM & Mean \pm SEM & C vs. C & $G_{1 v}$ s.C & $\mathrm{G}_{2} \mathrm{vs} . \mathrm{C}^{*}$ & $\mathrm{G}_{2}$ vs.C \\
\hline $\begin{array}{c}\text { T3 } \\
\mathrm{ng} / \mathrm{ml}\end{array}$ & $0.95 \pm 0.06$ & $2.50 \pm 0.12$ & $1.30 \pm 0.13$ & $0.55 \pm 0.18$ & 0.000 & 0.000 & 0.000 & N.S \\
\hline $\mathrm{T} 4 \mu \mathrm{g} / \mathrm{ml}$ & $1.75 \pm 0.05$ & $3.65 \pm 0.14$ & $4.76 \pm 0.33$ & $1.31 \pm 0.02$ & 0.000 & 0.000 & 0.000 & 0.000 \\
\hline $\begin{array}{c}\text { TSH } \\
\mathrm{MU} / \mathrm{ml}\end{array}$ & $0.73 \pm 0.06$ & $0.03 \pm 0.005$ & $0.7 \pm 0.06$ & $1.67 \pm 0.07$ & $0.000^{*}$ & $0.000^{*}$ & 0.000 & 0.000 \\
\hline
\end{tabular}

SEM: Mean standard error, ${ }^{\star} \mathrm{P}=<0.0001$ (highly significant), $\mathrm{P}=>0.05$ (N.S=No. significant)

The results in table(2) indicated that two month plant extract administration, shows a highly significant in the levels hormone T4 and TSH and no significant in level of T3, $(1.30 \pm 0.13),(4.76 \pm 0.33)$ and $(0.7 \pm 0.06)$ respectively compared to control groups $(0.95 \pm 0.06),(1.75 \pm 0.05)$ and $(0.73 \pm 0.06)$ respectively.

In the group where plant extract was given, for two months the levels of T3 and T4 $(1 \pm 0.1)$ and(1.8 \pm 0.2$)$ respectively were significant decrease and became nearly control groups. The results in table (2) indicated that one month plant extract administration, showes a significant decrease in the levels of hormones T3, T4, but TSH significant inecrease .

Thyroid hormone synthesis and secretion is regulated by the hypothalamic- pituitary - thyroid axis. Thyrotropinreleasing hormone $(\mathrm{TRH})$ released from the hypothalamus stimulates secretion of thyrotropin- stimulating hormone, TSH, from the anterior pituitary . TSH, in turn, is the physiologic stimulus for the synthesis and secretion of thyroid hormones, Lthyroxine $\left(T_{4}\right)$ and $L$ - triiodothyronine $\left(T_{3}\right)$, by the thyroid gland. Circulating serum $T_{3}$ and $T_{4}$ levels exert a feedback effect on both TRH and TSH secretion. When serum $\mathrm{T}_{3}$ and $\mathrm{T}_{4}$ levels increased, TRH and TSH secretion decrease. When thyroid hormone levels decrease, TRH and TSH secretion increase[19].

The mechanisms by which thyroid hormone exert their physiologic actions are not completely understood, but it is thought that their principal effects are exerted through control of DNA transcription and protein synthesis. $T_{3}$ and $T_{4}$ diffuse into the cell nucleus and bind to thyroid receptor proteins attached to DNA. This hormone nuclear receptor complex activates gene transcription and synthesis of messenger RNA and cytoplasmic proteins[20].

Levothyroxine Sodium has a narrow therapeutic index. Regardless of the indication for use, careful dosage titration is necessary to avoid the consequences of over - or under- treatment. These consequences include, among others, effect on growth and development, cardiovascular function, bone metabolism, reproductive function, cognitive function, emotional state, gastrointestinal function, and on glucose and lipid metabolism. Many drugs interact with levothyroxine sodium, necessitating adjustments in dosing to maintain therapeutic response [21].

In the present study, the prior administration of Vitis vinifera L. was significantly prevented the Levothyroxine sodiuminduced elevation in the levels of $T_{3}$ and $T_{4}$ may be due to the presence of therapeutic phytochemecals such as proanthocyanidins and natural poly phenolic $[22,23]$. In addition the Vitis vinifera L. leaves contain catecin and catechin derivares[24] or as much as the main function of thyroid hormone within physiologic ranges is to regulate and enhance metabolic reaction and oxygen consumption of different celles of the body. Reactive oxygen species (ROS) which are the by- products of tissue metabolism are normally treated by physiological antioxidants.

The role of thyroid in regulation oxidative stress is recently being explored. Previous reports showed that both hyper and hypothyroidism are associated with increased oxidative stress in human. Therefore extract aqueous of grape leaf could be work up as a regulator of hormone because it contain highly percent of antioxidant and possibly to return balance of thyroid hormone due to remove free radicals. 


\section{CONCLUSION}

This study shows that the levothyroxine sodium at $(5 \mu \mathrm{g} / \mathrm{kg})$ dose has a remarkable thyrotoxicosis effect and the aqueous extract of Vitis vinifera $L$. leaves administration prevented the toxic effect of levothyroxine sodium on the $T_{3}$, $T_{4}$ and $\mathrm{TSH}$ in rabbit females.

\section{REFERNCES}

[1] Jayaprakasha, G.K., Singh, R.P., and Sakariah, K.K.. 2001. Antioxidant activity of grape seed (Vitis vinifera) extracts on peroxidation models in vitro. Food Chemistry. 73:285-290

[2] Mohammed, K.Gh., Mojdeh, N.H., and Akbar, H. 2005. Vasorelaxatory Effect of Vitis vinifera Extract on Rat Aorta. Iranian Journal of Pharmaceutical Research. 2:93-99.

[3] Jean-Frederic, T., Elidie ,T., Laurent ,B., Sarah, I., and et al. 2010. Evolution and history of grapevine (Vitis vinifera)under domestication: new morphometric perspectives to understand seed domestication syndrome and reveal origins of ancient European cultivars. Annals of Botany. 105:443-455.

[4] Parry, J., Su, L., Moore, J ., and et al. 2006. Chemical composition, antioxidantcapacities, and antiproliferative activities of selected fruit seed flours. Journal Agriculture Food Chemistry. 54(11):3773-8.

[5] Gharib, M.K., Zarei, M., and Amiri, O. 2006. Spasmolytic effect of Vitis vinifera leaf extract on rat colon. DARU. 14(4):203-207.

[6] Arroyo, R., Ruiz, L., Bolling, L., Ocete, R., and Lopez, A. 2006. Multiple origins of cultivated grapevine (Vitis vinifera L. ssp. sativa) based on chloroplast DNA polymorphisms. Molcular Ecology.15:3707-3714.

[7] Martina, B., Paul, A., and Ary, A. 2005.Eriophyoid mite damage in Vitis vinifera (grapevine) in Australia: Calepitrimerus vitis and Colomerus vitis(Acari: Eriophyidae) as the common cause of the widespread Restricted Spring Growth'syndrome. Experimental and Applied Acarology. 35:83-109.

[8] Djelic, N., Nesic, I., Stanimirovic, Z., and Jovanovic, S. 2007. Evaluation of the genotoxic effect of thyroxine using in vivo cytogenetic test on swiss albino mice. Acta Veterinaria (Beograd). 57(5-6):487-495.

[9] Marilyn, R.B., and Dale, W. H. 2002. The effect of thyroxine on metabolism and water balance in a desert- dwelling rodent, Merriam's kangaroo rat(Dipodomys merriami). Journal of Comparative Physiology B. 172:17-25.

[10] Elmas, G., Canan, O., and Nuriye, A. 2008. Interaction of Thyroxine with 7 Hydroxycoumarin: A Fluorescence Quenching Study. Journal of Flouresc.18:781-785.

[11] Chopra, I.J. 1972. A radioimmunoassay for measurements of thyroxine in unrestricted serum. J. Clin. Endocrin. And Metab, 34: 938.

[12] Siddiqui, AA., and Ali, M. 1997. Practical Pharmaceutical Chemistry, $1^{\text {st }}$ ed, CBS publishers and distributors. New Delhi.Pp 126-131.

[13] Sharma, P., and Gujral, HS. 2010. Antioxidant and polyphenol oxidase activity of germinated barley and its milling fractions. Food Chem. 120: 673-678.

[14] Lyenger, MA. 1995. Study of Crude Drug. $8^{\text {th }}$ ed. Manipal Power Press. Manipal, India. p:2.

[15] Anita, R. Sh., And Anupam, Sh. 2012. Anti- anxiety and CNS modulatory activities of Vitex aguns- castus Linn. Phytopharamacology. 3(1): 29-37.

[16] Alexander, P., and Lundgren, H.P. 1966. A Laboratory Manual of Analttical Methods of protein chemistry. Vol 1-5, Oxford, Pergamon Press.

[17] Wuttke, W., Jarry, H., Christoffel, V., Spengler, B., and Seidlova- Wuttke, D. 2003. Chast tree cvitex aguns-castus. Pharmacology and clinical indications. Experimental Clinical Endocrinsology Diabetes. 10: 348-357.

[18] Kapoor, LD., Singh, A., Kapoor, SL., Srivastava, SN. 1969. Survey of plants for saponins. alkaloids and flavonoidsl. Lloydia. 32:297-304.

[19] Adlercreutz, H. 2007. Lignans and human health. Critical Reviews in Clinical Laboratory Science. 44(5-6): 483-252.

[20] Anderson, D., Schmid, TE., Baumgartner, A., Cemeil-Carratala, E., Brinkworth, M., and Wood, JM. 2003. Osetrogenic compounds and oxidative stress(in human sperm and lymphocytes in the Comet assay). Mutat Res. 544:173-8.

[21] British Thyroid Foundation, 2009. Signs and Symptoms of Hypothyroidism. Available from:http://www.brt-thyroid. Org/Accessd 17 Novmber 2009.

[22] Abeer, M. W. 2012. Grape Seed Extract (Vitisvinifera) Alleviate Neurotoxicity and Hepatotoxicity Induced by Lead Acetate in Male Albino Rats. Journal of Behavioral and Brain Science. 2: 176-184. 
[23] Leelavinothan, P., and Arumgam, S. 2008. Effect of grape (Vitis vinifera L.) leaf extract on alcohol induced oxidative stress in rats. Food and Chemical Toxicology. 46(5): 1627-1634.

[24] Nilufer, S., and Mustafa, A. 2006. Antidiabetic and antioxidant effects of Vitis vinifera L.leaves in streptozotocindiabetic. Turkish J. Pharm. Sci, 3(1): 7-18. 